\title{
Commercial Litigation in Europe in Transformation: The Case of the Netherlands Commercial Court
}

\author{
Eddy Bauw*
}

\begin{abstract}
The judicial landscape in Europe for commercial litigation is changing rapidly. Many EU countries are establishing international business courts or have done so recently. Unmistakably, the approaching Brexit has had an effect on this development. In the last decades England and Wales - more precise, the Commercial Court in London - has built up a leading position as the most popular jurisdiction for resolving commercial disputes. The central question for the coming years will be what effect the new commercial courts in practice will have on the current dominance of English law and the leading position of the London court. In this article I address this question by focusing on the development of a new commercial court in the Netherlands: the Netherlands Commercial Court (NCC).
\end{abstract}

Keywords: International business courts, Netherlands Commercial Court, choice of court, recognition and enforcements of judgements

\section{Introduction}

The judicial landscape in Europe for commercial litigation is changing rapidly. Many European Union (EU) countries are establishing international business courts or have done so recently. ${ }^{1}$ Unmistakably, the approaching Brexit has had an effect on this development. In the last decades, England and Wales - more precisely, the

\footnotetext{
Professor of Private Law and Administration of Justice at Molengraaff Institute for Private Law and Montaigne Centre for Rule of Law and Administration of Justice, Utrecht University. Substitute judge at the Court of Appeal of Arnhem-Leeuwarden and the Court of Appeal of The Hague. This article is based partly on a contribution to a seminar on Innovating International Business Courts, held on 10 July 2018, at Erasmus University Rotterdam, and partly on some of the author's earlier publications on the topic.

1. The Chamber for International Commercial Disputes at the Landgericht Frankfurt am Main (from January 2018), in Germany, and la Chambre Commerciale au sein de la Cour d'appel de Paris (from February 2018), in France, have been active since last year. In Belgium, in December 2018, a bill was presented to parliament with the aim of establishing a Brussels international business court (Parl.St. Kamer 2018-19, nr. 3072/011). In Germany, also, a bill providing for the setting up of chambers for international commercial disputes within a state's regional court is pending in parliament, seewww.bundesrat.de/SharedDocs/ drucksachen/2018/0001-0100/53-18.pdf?_blob=publicationFile \&v=1 (last visited December 2018).
}

Commercial Court in London - has held the leading position as the most popular jurisdiction for resolving commercial disputes. ${ }^{2}$ The central question for the coming years is the effect that the new commercial courts in practice will have on the current dominance of English law and on the leading position of the London court. This article addresses this question by focusing on the development of a new commercial court in the Netherlands: the Netherlands Commercial Court (NCC). First, the reasons for the establishment (Section 2), the organisation (Section 3) and the jurisdiction (Section 4) of the NCC are discussed. Then the main features of the Rules of Procedure of the NCC (Section 5) are described. This is followed by consideration of the establishment of the NCC from a broader perspective and an attempt to assess the chances of its success (Section 6) and investigate its possible impact on civil litigation in the Netherlands (Section 7). The discussion closes with a few concluding remarks (Section 8).

\section{Why a Netherlands Commercial Court}

Plans for the establishment of a Netherlands Commercial Court were initiated long before any discussion cropped up about a Brexit referendum. In fact, the first time the subject was placed on the table was when the Netherlands Scientific Council for Government Policy published the report 'The Netherlands, a trade country, the perspective of transaction costs' in $2003 .{ }^{3}$ One of the recommendations of the council was to make it possible, in the light of the importance of international trade for the country, to litigate in English in Dutch courts. Although there was some discussion on the topic at the time, this recommendation lay dormant for years, until the idea was picked up by the Netherlands Council for

2. As is shown in a number of surveys discussed by E. Themeli, 'The Great Race of Courts, Civil Justice System Competition in the European Union' (PhD thesis, Erasmus University Rotterdam), at 254 et seq. See also C.J.E. Brouwer and J.L. Butijn, 'The Netherlands Commercial Court: An International Perspective', in: E. Bauw, H. Koster \& S.A. Kruisinga (Eds.), De kansen voor een Netherlands Commercial Court, Montaigne Serie nr. 9, (2018), at 155-85.

3. Wetenschappelijke Raad voor het Regeringsbeleid (WRR), Nederland handelsland. Het perspectief van de transactiekosten, The Hague 2003. 
the Judiciary in 2014 in the form of a plan to establish a Netherlands Commercial Court. The Council for the Judiciary had several reasons for this initiative.

The first was that, while international trade by Dutch businesses had increased, the number of commercial cases with an international dimension for the Dutch courts had decreased considerably in the preceding years. Further analysis showed that the choice of Dutch courts in international business contracts had decreased dramatically as well. This was and is noticeable in all areas of business, including international transport cases where the District Court of Rotterdam traditionally had an excellent reputation. The reason for this decline is that in international business contracts the choice of the London Commercial Court as the competent court has become the default option. ${ }^{4}$ Dutch companies are increasingly being forced to agree to this choice, the outcome of which is higher costs. The costs of litigation are considerably higher in the UK, especially in London, than in the Netherlands. For the Dutch courts, it leads to a loss of interesting high-profile and highimpact cases, making the total 'work package' of judges less interesting. This is certainly not an advantage when courts want to attract the best lawyers. Dutch courts already have difficulties recruiting new judges. ${ }^{5}$ If this situation continues for long, a point of no return will be reached. The number of judges with knowledge of and experience with these sorts of cases will decrease further every year. The same goes for the legal services sector in the Netherlands. The Council for the Judiciary has foreseen long-term negative consequences for the judiciary and for the Dutch legal sector as a whole if this development is allowed to continue.

The decline in the number of international commercial cases is all the more disturbing in the light of the high quality of the Dutch judiciary, and this is not merely a matter of opinion, as the annual global so-called Rule of Lam Index of the World Justice Project shows the Netherlands in the overall fifth place and even in the first place for civil justice for the past 5 years or more. ${ }^{6}$ In the Global Competitiveness Index, an authoritative annual international ranking of countries in the field of competitiveness and trade position, of the World Economic Forum, the Netherlands has, for years, scored high on elements that strongly influence the choice of parties in favour of a judicial forum, namely judicial independence (fourth place) and efficiency of legal framemork in settling disputes (sixth place). ${ }^{7}$ This stable high ranking is the result of a modern civil procedural law that leads to an efficient procedure and relatively short lead times com-

4. As clearly follows from the surveys discussed by Themeli, above n. 2, at 269 et seq.

5. E. Bauw, 'Wat te doen aan het rechterstekort?', 10 Ars Aequi 10 (2017), at 850-53.

6. Seehttps://worldjusticeproject.org/sites/default/files/documents/WJPROLI-2018-June-Online-Edition_0.pdf. Last visited December 2018.

7. K. Schwab (red.), 'The Global Competitiveness Report 2018', Geneva: World Economic Forum (2018), available at: https:// www3.weforum.org/docs/GCR2018/05FullReport/

TheGlobalCompetitivenessReport2018.pdf (last visited December 2018). pared with those of many other countries. ${ }^{8}$ Furthermore, the Netherlands has an open economy, a long tradition of trade, a politically neutral profile and a highlevel legal sector. The further modernisation of the civil procedure (in short, faster and more digitally) through the recent legislation on 'Quality and Innovation' (KEI), which is currently being implemented, could lead to an even better international ranking. The Netherlands has a long tradition of trade and the settling of trade disputes. The Dutch Bar is of high calibre with a clear international focus, as reflected by the presence of many international law firms, especially in the Amsterdam area. Last but not least, the Netherlands is an EU member state and has many bilateral treaties relating to recognition and enforcement of civil judgments, an issue that will be addressed later in this contribution.

In view of the foregoing merits, the idea grew that there was no reason to passively accept the downward trend. ${ }^{9}$ Through the creation of a specialised court with excellent modern facilities and by offering the possibility to litigate in English, the Dutch judiciary should be able to compete with other legal systems in international commercial cases. A plan was drawn up to establish a Netherlands Commercial Court (hereafter referred to as 'the NCC plan') and was published in November 2015 on the website of the judiciary rechtspraak.nl. ${ }^{10}$ The plan was based on marketing research and discussion with relevant businesses to gauge their enthusiasm for the idea. The outcome was that such a facility, indeed, has potential. On the basis of this research, a business case was drawn up with a first estimate of the investment needed for the establishment of a Netherlands Commercial Court and the quantum of revenues expected to flow from this investment. The business case helped to convince the minister of justice and spurred him to initiate the necessary legislation.

\section{Organisation and Facilities}

The groundwork for the design of the NCC is laid down in a bill that was presented to the House of Representatives ('Tweede Kamer') in July 2017. ${ }^{11}$ The bill passed the House in March 2018 and was sent to the Senate ('Eerste Kamer'). ${ }^{12}$ On 11 December 2018, the bill, and thereby the establishment of the Netherlands Commer-

8. Hence, the high ranking for the efficiency of the legal framework in settling disputes.

9. See, for more background information on the establishment, R.A. Boon, 'De Netherlands Commercial Court - van idee tot oprichting,' in: E. Bauw, H. Koster \& S.A. Kruisinga (eds.), De kansen voor een Netherlands Commercial Court, Montaigne Serie nr. 9 (2018), at 37-47.

10. Waarom een Netherlands Commercial Court? Plan tot oprichting van een Netherlands Commercial Court, inclusief kosten-baten-analyse, Raad voor de rechtspraak, 25 November 2015, available at: www.rechtspraak.nl/SiteCollectionDocuments/20150120-PlanNetherlands-Commercial-Court.pdf\#search=netherlands \%20commercial\%20court (last visited December 2018).

11. Kamerstukken I/ 2016/17, 34 761, nrs. 1-3.

12. Kamerstukken / 2017/18, 34 761, C. 
cial Court, received the approval of the Senate. ${ }^{13}$ The NCC legislation entered into force on 1 January 2019. ${ }^{14}$

There are two issues that are regulated in the NCC legislation. The first concerns the use of English in the proceedings and the judgments of the NCC. Oddly enough, there is no statutory provision that prescribes that litigation before the Dutch courts should be in Dutch. This was probably considered self-evident. In practice, courts already allow the use of other languages in proceedings, and judges regularly conduct hearings in German or English if required by a case. In fact, the District Court of Rotterdam has experimented with the use of English in proceedings in international transport cases since 2016, having adopted special procedural rules for this. ${ }^{15}$ Also, the Enterprise Chamber of the Amsterdam Court of Appeal has had for years a practice of accepting documents in English and of using English during court hearings. However, the possibility of delivering a written judgment in English needs an undisputable legal basis, and there should be no room for doubt with regard to the legality of a judgment. Therefore, the NCC legislation is needed to allow judgment in English by the NCC. For this, a new Article $31 \mathrm{r}$ is added to the Dutch Code for Civil Procedure (CCP).

The second point that is addressed in the NCC legislation is the court fees. It is intended that the costs of the NCC can be financed from the proceeds of the court fees. In other words, the NCC must - apart from the initial costs - be financially self-supporting. However, the current court fees for commercial cases are too low to cover these costs, so separate pricing for these cases is necessary. Of course, at the start, there is insufficient data for an exact calculation, and therefore an assessment is made. The court fee for the NCC is based on three elements: the estimates of the number of cases to be expected, ${ }^{16}$ the average costs of handling a case ${ }^{17}$ and the tariffs of other commercial courts. This leads to a court fee of $€ 15,000$ for the court of first instance and $€ 20,000$ for the court of appeal. Additionally, interim relief proceedings at the NCC chamber of the Amsterdam District Court will cost €7,500, and interim proceedings at the NCC chamber of the Amsterdam Court of Appeal will cost $€ 10,000$. $^{18}$ The NCC legislation adds these special court fees to the Act on Court Fees for Civil Cases ('Wet griffierecht in burgerlijke zaken').

This brings us to the other main features of the Netherlands Commercial Court, namely the organisation and the jurisdiction of the NCC, followed by the rules of

13. Wet van 12 december 2018 tot wijziging van het Wetboek van Burgerlijke Rechtsvordering en de Wet griffierechten burgerlijke zaken in verband met het mogelijk maken van Engelstalige rechtspraak bij de internationale handelskamers van de rechtbank Amsterdam en het gerechtshof Amsterdam, Staatsblad 2018, 474

14. Royal Decree of 18 December 2018, Staatblad 2018, 475.

15. Seewww.rechtspraak.nl/SiteCollectionDocuments/Procedure-Rules-forproceedings-in-English.pdf (last visited December 2018)

16. The NCC-plan estimates that the average number of cases will be 100 in the first instance and 25 in appeal, NCC-plan, at 16.

17. These costs consist mainly of the time the judges and the support staff spend on a case.

18. The court fees are the same for natural persons and legal persons. procedure, which are dealt with in the next section. In regard to the organisation of the court, it should be noted that the NCC will be a court only in name, but in reality a specialised division or chamber of the Amsterdam District Court and of the Amsterdam Court of Appeal, as there are other specialised chambers of courts. Both chambers will be specialised in dealing with complex international commercial disputes. These 'Chambers of International Trade Disputes' are presented externally as 'Netherlands Commercial Court' and 'Netherlands Commercial Court of Appeal'. The two chambers are not filled solely with judges from the Amsterdam courts but from a national pool of judges ('the NCC-pool') who have been selected for this on the basis of specialised knowledge and their English language skills, among other things. The judges are given special training, in addition to their existing knowledge and skills. All judges, it should be emphasised, are Dutch judges, as required by Dutch law, and no exception is made for the NCC. This differs from arbitration and other commercial courts, for example in Dubai and Singapore, which have arbitrators and judges of various nationalities.

The court sessions will take place in the building of the Amsterdam Court of Appeal ('the Palace of Justice') at the IJdock waterfront. The court and the parties will be able to make use of the modern facilities available in this modern court building. These include the possibility of calling in court reporters, who make a verbatim report of a hearing in the court, if so desired by the parties and at their expense. In line with the new 'KEI-legislation' (Article 30n CCP), the judge can also opt to have video and/or sound recordings made to replace the traditional official report. The new NCC procedure is also in line with KEI in regard to digital litigation, although a separate portal for NCC cases has been developed: the eNCC. ${ }^{19}$ The aim is to enhance efficiency by direct (electronic) communication between the judge and the parties. Litigation before the court will also be conducted electronically. All submissions, including a claim or defence, exhibits, applications, requests and notifications to the court, will have to be uploaded to the NCC's portal and will be added to an electronic case file (Article 3.2. NCCR). ${ }^{20}$ Finally, the court will be able to make use of teleconference and videoconference facilities if it so desires.

All cases will, in both instances, be heard and decided by a three-judge panel (Article 3.5.1 NCCR), unlike, of course, the practice in the London Commercial Court, where, as befits the common law tradition, cases in the first instance are decided by a single judge. Decisions in the first instance will be open to appeal to the NCC

19. See in more detail L.S. Frakes, 'NCCR en eNCC: goede communicatie in internationale handelszaken', in: E. Bauw, H. Koster \& S.A. Kruisinga (Eds.), De kansen voor een Netherlands Commercial Court, Montaigne Serie nr. 9 (2018), at 101-111. See, however, also n. 22 below.

20. Note that litigation before the NCC will not be conducted electronically at the start of the NCC on 1 January 2019 (see the addendum to the NCC Rules of procedure of 20 December 2018, Staatscourant 2018, 71575). See further n. 22 below. 
division of the Amsterdam Court of Appeal and subsequently in cassation before the Supreme Court of the Netherlands ('Hoge Raad'). While proceedings at both divisions of the NCC will be - as already stated - conducted in English, as will delivery of judgments, this will not be the case at the supreme court, where proceedings and judgments will be in Dutch. This has to do with the fact that cassation is limited to questions of law and that the judgments of the supreme court have important precedential effect in Dutch private law and for all Dutch courts. This makes it important to stay close to the terminology that is commonly used in Dutch private law and the precise formulations that the supreme court uses in its rulings.

Parties can, while making a choice for the NCC, exclude the possibility of appeal and cassation. They can also make use of the possibility to begin summary proceedings ('Court in Summary Proceedings in the NCC District Court', CSP, Article 6.3 NCCR) for provisional relief before or during NCC proceedings. These summary proceedings are dealt with by a single NCC judge. And, as in all civil cases in the Netherlands, the NCC will be able to refer questions to the supreme court for a preliminary ruling ('prejudiciële procedure'). ${ }^{21}$ Parties must be represented by a lawyer who is a member of the Dutch Bar (Article 3.1 NCCR). All submissions must be done by this lawyer. Lawyers of other EU member states may act for a party in other ways in cooperation with the Dutch Bar member. Non-EU lawyers may not act for a party, but the court may allow them to speak at any hearing.

\section{Jurisdiction}

The next question is the types of cases that can be brought before the court. First, the jurisdiction is restricted to civil or commercial matters in connection with a particular legal relationship within the autonomy of the parties and that is not subject to the jurisdiction of the sub-district court or the exclusive jurisdiction of any other chamber or court (Article 1.3.1(a) NCCR). This means that parties cannot opt for the NCC as a forum in all civil or commercial matters with an international aspect. Although there is no minimum financial threshold for claims brought before the NCC, disputes that fall under the competence of the sub-district court (the so-called 'kantonrechter') are left outside its scope. Therefore, financial claims under $€ 25.000$ and disputes concerning consumer purchases or consumer credits, rental disputes or labour disputes cannot be brought before the NCC. However, because of the high court fee, even without this restriction it is very unlikely that claims with a low financial value will be brought before the NCC. Another restriction is that disputes falling within the exclusive jurisdiction of other existing specialised courts such as the Enterprise Chamber of the

21. Art. $392 \mathrm{CCP}$
Amsterdam Court of Appeal and the Patent Chamber of the District Court of The Hague are outside the competence of the NCC.

Second, the matter must concern an international dispute (Article 1.3.1 (b)) NCCR). According to the explanatory memorandum to the NCCR, a matter has an international aspect when:

a. At least one of the parties to the proceedings is resident outside the Netherlands or is a company established abroad or incorporated under foreign law, or is a subsidiary of such company.

b. A treaty or foreign law is applicable to the dispute or the dispute arises from an agreement prepared in a language other than Dutch.

c. At least one of the parties to the proceedings is a company or belongs to a group of companies, of which the majority of its worldwide employees work outside the Netherlands.

d. At least one of the parties to the proceedings is a company or belongs to a group of companies, of which more than one half of the consolidated turnover is realised outside the Netherlands.

e. At least one of the parties to the proceedings is a company or belongs to a group of companies, the securities of which are traded on a regulated market, as defined in the Dutch Financial Supervision Act ('Wet financieel toezicht', Wft), outside the Netherlands.

f. The dispute contains legal facts or legal acts outside the Netherlands.; or

g. The dispute, otherwise, involves a relevant cross-border interest.

This list of examples is not exhaustive, and the further interpretation is left to the $\mathrm{NCC}(\mathrm{A})$ and, in the last resort, to the supreme court.

Third, the parties should have designated the Amsterdam District Court as the forum to hear their case, or the Amsterdam District Court has jurisdiction to hear the action on other grounds (Article 1.3.1 (c) NCCR). Lastly, it is required that both parties have expressly agreed that the proceedings will be in English and will be governed by the Rules of Procedure of the NCC (Article 1.3.1 (d) NCCR). These rules will be revisited later on. Parties thereby also (implicitly) accept to pay the special court fee for the NCC.

\section{Rules of Procedure}

Although the common Dutch procedural law (the Dutch Code of Civil Procedure, Wetboek van burgerlijke rechtsvordering, hereafter referred to as CCP) will apply in full in NCC cases, additional special rules of procedure were drawn up for the proceedings at the NCC: the NCC rules, NCCR). ${ }^{22}$ These rules are comparable

22. Published in Staatscourant 2018, nr. 71572, with addendum in Staatscourant 2018 71575, available at: www.rechtspraak.nl/ SiteCollectionDocuments/concept-procesreglement-ncc_en.pdf (last 
to the practice directions of the London Commercial Court. ${ }^{23}$ The NCCR partly have the function of providing clarifications of Dutch procedural law. Attached to them is a glossary of translations of Dutch legal terms into English. For practical purposes, the rules give foreign lawyers a short introduction to Dutch procedural law. In addition, the rules deviate somewhat from the rules of procedure for other commercial civil cases, specifically with the aim of promoting efficient and effective handling of large international commercial cases. They are drawn up to lead to litigation that is sufficiently interesting for parties to international commercial contracts to make a choice of the NCC in the forum selection clause in their contract. In addition, the parties can further 'design' the procedure by concluding an agreement as to proceedings. The NCCR highlight the choices that can be made here, for instance with regard to the taking of evidence or the evidential value of certain documents (Article 153 CCP and Article 8.3 NCCR). This offers room - if parties so desire - to bring certain typical Dutch rules, such as the rules governing the evidential value of the party witness's statement (Article 164 para. 2 Dutch Code of Conduct, Section 8.5 .5 of the NCCR), more in line with international standards.

The drafters of the NCCR have strived for a structure that is 'understandable at a glance for lawyers in international business practice', because this is 'of great importance to advise clients on the choice to litigate at the NCC'. ${ }^{24}$ The result is that the NCCR, while rooted in Dutch procedural law, contains a number of elements that are derived from the procedure at the London Commercial Court. An example is the 'guarantee' in Article 3.5.2 NCCR that judges and court officials who have been assigned a case will continue to deal with the case until the end ('dedicated judge'). This judge should, for instance, consider preliminary evidence transactions, such as a provisional witness examination (Article $186 \mathrm{CCP}$ ) or a preliminary report or hearing of an expert witness (Article 202 CCP). Although the principle of the dedicated judge is also a principle of Dutch procedural law, the practice differs in that a civil case is usually (only) linked to a judge (the 'case judge') after the statement of defence has been received, following which an oral hearing will take place. After this hearing, restrictions and requirements are imposed on possible court changes. However, in the litigation of commercial cases at the Commercial Court in London, case management by the judge starts at an earlier stage in the proceedings, especially with regard to the gathering of evi-

visited December 2018). It is important to note that, because of the delay in the implementation of the aforementioned KEI legislation, this legislation will for the time being not apply to NCC cases. Instead, the current Dutch CCP will remain in force. The most important consequence is that litigation before the NCC will not be conducted electronically. The rules in the NCCR with regard to eNCC will not apply at the start of the NCC. Measures are taken to keep this period as short as possible.

23. The directions can be found on www.justice.gov.uk/courts/procedurerules/civil/rules. Last visited December 2018.

24. Frakes, above n. 19, at 101-111 dence in the phase prior to the oral hearing. Since this practice is adopted by the NCC, it is obvious that, for reasons of consistency and efficiency, from this moment on in the procedure the judge who will take charge of the case management should not, subject to (high) exception, be changed.

Important for the choice of forum that parties to an international commercial contract will make is, evidently, the speed of the proceedings of a court. With regard to the latter, the Dutch Code for Civil Procedure contains a general obligation for judges and parties to facilitate the just, fair and speedy disposition of a case and, wherever possible, prevent any unreasonable delay (Article 20 CCP). Apart from this, the special proceedings at the NCC seek to promote the expedience of the procedure in three ways (Article 3.4 NCCR). First, at the beginning of the proceedings the court will order a case management conference in which one of the judges discusses with the parties whether a settlement can be reached and, if not, how the case will be handled. This coincides well with the intention of the recent reform of the CCP ('Quality and Innovation', KEI): 'The courts make it possible for a case to be assigned to a judge at an early stage of the proceedings, so that if necessary they also have a hearing aimed at the direction of the case prior to the substantive oral examination, either at the request of the parties or not'. ${ }^{25}$ Holding a case management conference is particularly important in the preparatory phase of the procedure in which evidence collection takes place. What kind of pretrial discovery will be allowed, will there be a hearing of witnesses and so on? Thus, the course of the proceedings is adapted to the complexity and value of the case.

Second, the court sets strict time limits of between 2 and 6 weeks for the different acts of process (Article 3.4 NCCR). Extensions are granted only for compelling reasons, unless parties make a unanimous request for extension of these limits. And even then the court can dismiss this request if this would cause unreasonable delay. Also, the Dutch inquisitorial trial model that is characteristic of civil law legal systems, as opposed to common law legal systems, adds to the efficiency of the proceedings. The Dutch judge has a more active role at trial than does - for example - the English judge.

Third, the efficiency and speed of the proceedings are favoured by the Dutch rules with regard to disclosure that are included in the rules of procedure. In most common law systems - such as that of England and Wales - the obligations for parties to disclose documents at the request of the other party are quite extensive. In commercial cases, the stakes are often very high, as is the importance of factual evidence to win the case. The possibilities under English law to force the other party (or third parties) to submit documents (the socalled 'disclosure') are considerable. These possibilities are much broader than the claim in court for the exhibition of certain documents under Article 843a CCP and

Kamerstukken I/ 2014/15, 34059, 3, at 27. 
Article 8.4 of the NCCR. ${ }^{26}$ This will lead to considerably lower litigation costs compared with, for instance, those of the London Commercial Court. In the 'competition' with other commercial courts, this will be a potential selling point for the NCC.

However, as one might expect, the 'competition' does not sit still. In the UK, there has been an ongoing discussion on disclosure for years before Brexit. It is criticised especially because of the high costs that it creates. ${ }^{27}$ For years this discussion had no clear outcome, but a change has recently been detected here. Since 2017 a more restrictive course seems to have been adopted in high court judgments. ${ }^{28}$ In 2018, a draft for new rules on disclosure has been drawn up by a working group of the high court and adopted by the Civil Procedure Rule Committee in July. ${ }^{29}$ A 2-year 'Disclosure Pilot' for the Business and Property Courts based on these rules will begin on 1 January 2019 with the aim of restricting the current practice at the commercial court and is a breakthrough in the long-running discussion within the court. It is evidently the pressure of the rise of new business courts that helped to steer the discussion in this direction. Of course, the pace at which the change of rules will be able to change practice remains to be seen.

\section{Chances of Success}

A description of the contours of the NCC and its proceedings having been provided, the following questions must now be asked: What are the prospects of the Netherlands Commercial Court becoming a success? Will it be able to compete with the existing business courts in and outside the EU? Because the establishment of the NCC is without precedent, it is impossible to make a reliable prediction. One can only make a reasoned estimate of the considerations that are likely to determine the choice of potential users of commercial courts.

In this context, the recent $\mathrm{PhD}$ thesis of Erlis Themeli is of interest. ${ }^{30}$ In his thesis, Themeli first ranks the ability of EU member states to compete in the 'civil justice system competition' using data collected for the EU Justice Scoreboard (2016). The scoreboard is a collection of data on the quality of the judicial system in all

26. Even when the scope of Art. 843a CCP has been somewhat extended by the supreme court, e.g. in HR 26 October 2012, ECLI:NL:HR: 2012:BW9244, NJ 2013/220 and HR 10 July 2015, ECLI:NL:HR: 2015:1834, NJ 2016/50

27. See, e.g., recommendation 6.4 in the report 'Review of Civil Litigation Costs: Final Report' of December 2009: 'Disclosure can be an expensive exercise (particularly in higher value, complex cases), and it is therefore necessary that measures be taken to ensure that the costs of disclosure in civil litigation do not become disproportionate.'

28. Tchenguiz \& Anor v. Grant Thornton UK LLP \& Ors [2017] EWHC 310 (Comm) (22 February 2017) en Grosvenor Chemicals Ltd \& Ors v. UPL Europe Ltd \& Ors [2017] EWHC 1893 (Ch) (26 July 2017).

29. Seewww.judiciary.uk/wp-content/uploads/2018/07/pressannoucement-disclosure-pilot-approved-by-cprc.pdf (last visited December 2018).

30. Themeli, above n. 2, at 269 et seq the member states. He ranks the Netherlands as the second-best scoring EU member state (behind Luxembourg) in the 'civil justice system competition' and concludes that it 'is well equipped to compete within the EU' ${ }^{31}$ Next, Themeli presents the findings of his survey among lawyers working for the biggest law firms in the EU. ${ }^{32}$ The questions in the survey were related to their practical professional experience and their preferences with regard to the choice of court. The survey shows that of paramount importance to this choice are 'quality of judges', 'lack of corruption' and 'neutrality'. ${ }^{33}$ These factors can be collectively characterised as the 'quality and integrity of the justice system'. Not very surprisingly, it is fundamental for the trust of lawyers that in the case of a dispute about the contract their clients will have 'a fair trial and decision'. In regard to the position of the NCC on this aspect, the high ranking of the Dutch justice system in the international rankings, referred to in Section 2, is again relevant. In the Global Competitiveness Index 2018, the Netherlands holds the fourth place in the pillar 'institutions'. ${ }^{34}$ Apart from the components already mentioned in Section 2, this pillar consists of components that will determine the aforementioned trust, especially 'judicial independence' (4th place) and 'incidence of corruption' (8th place). On all these aspects, the Netherlands (judiciary) ranks among the top ten, securing it an overall fourth place. In the Rule of Lam Index of the World Fustice Project, the Netherlands ranks fifth. It therefore seems safe to say that this factor will at least not work against a choice in favour of the NCC.

The second factor that, according to the findings in the thesis, determines the choice of court is the 'speed of dispute resolution'. This factor has already been addressed in Section 2 of this article, in the context of the high ranking enjoyed by the Dutch judiciary in the comparative efficiency of the legal framework in settling disputes (eighth place) and the provisions on case management and time limits in the NCCR that aim to promote the speed of the proceedings (Section 5). Of course, the NCC will have to prove in practice what it has to offer in this respect, but since the basic position of the Dutch judiciary with regard to this factor is advantageous and the NCCR seek to further improve this, with regard to this aspect, the starting position seems favourable in comparison with many other European judiciaries that have lower positions in these rankings and longer handling times.

The third factor is the 'predictability of the outcome'. This predictability connects strongly to the choice parties make in their business contracts with regard to the applicable law. Although this is, of course, possible, it is not very likely that parties will opt for English law and

31. Themeli, above n. 2, at 249

32. He also discusses other similar surveys as the study by the Oxford Institute of European and Comparative Law and Oxford Centre for SocioLegal Studies on 'Civil Justice Systems in Europe', Themeli, above n. 2, at 270 et seq.

33. See Q15 at 295, Q17 at 298 and Q18 at 300 combined.

34. Schwab, above n. 7 
at the same time for the NCC as the forum to adjudicate the disputes arising out of the contract. It is self-evident that both choices in most cases will go together. What has been noted earlier about the choice of court clause, namely that London is the default choice in international business contracts, also applies to the choice of law: The default choice is English law. In recent decades in business circles - or, more precisely, in circles of international business lawyers - the image has become dominant that English law offers more legal certainty and predictability to contracting parties than other legal systems, especially, of course, when applied by English judges. A closer look at the matter reveals that the differences between Dutch and English civil law are not as big as they, at first sight, appear to be. ${ }^{35} \mathrm{~A}$ more nuanced image would therefore be more appropriate. However, especially lately, the UK seems to promote more strongly than ever the image that English common law is superior to the laws of other, especially civil law, countries. A recent brochure titled 'English Lam, UK Courts and UK Legal Services after Brexit. The viem beyond 2019', lists all the benefits of a choice of English law. The main selling point is that English law is more predictable and therefore offers more business certainty: 'Contracts governed by English Law are interpreted primarily by reference to the language which the parties themselves have agreed. Stringent requirements must be met before terms will be implied into the parties' bargains and the words in a contract will not be given a meaning contrary to business common sense'. ${ }^{36}$

Although Dutch civil law is not very different from what is described here, the UK has very successfully created the impression that the choice of law other than English puts businesses in troubled waters. ${ }^{37}$ There are, however, good arguments for parties to choose Dutch law. Dutch civil law has a long commercial tradition and is widely acknowledged as modern and practical. It (also) offers legal certainty and, at the same time, is flexible and non-dogmatic. But, still, the 'image' of Dutch contract law is different. The fear that Tjittes so strikingly called 'fides phobia' seems to be deeply rooted in the 'hearts and minds' of international business lawyers. ${ }^{38}$ In particular, the use of such concepts as 'reasonableness and fairness' and 'good faith' are considered a threat to 'business certainty'. It will not be easy to prove otherwise. It seems to be more a matter of communication and marketing than of legal substance. Of course, this will take years, and the NCC must first attract cases to be able to show how predictable and, at the same time, adaptable Dutch private law can be. Perhaps this is even the biggest challenge for the NCC, namely to

35. See for a comparison R.P.J.L. Tjittes, 'Een Netherlands Commercial Court vereist reclame voor Nederlands recht', RM Themis 2014-6, at 61-62, ibid., Op de golven van de goede trouw naar Engels contractenrecht, RM Themis 2015-5, at 208-18 and ibid., Commercieel contractenrecht, Den Haag: Boom juridisch 2018.

36. See www.lawsociety.org.uk/Policy-campaigns/documents/uk-legalservices-after-brexit/ (last visited December 2018).

37. Tjittes (2015), above n. 35.

38. Ibid. convince businesses and their legal counsels and business lawyers that they should not automatically stick to the model choice of law and dispute resolution clauses that they use for their contracts but modify them in the light of new circumstances and developments.

The fourth factor mentioned in the survey as an important element in the choice of court is the 'enforcement possibilities'. Owing to instruments like the Brussels I Regulation (recast) ${ }^{39}$ and the Lugano Convention, ${ }^{40}$ Dutch court judgments are enforceable in the EU, Switzerland, Norway and Iceland. And when more countries ratify the Convention on Choice of Court Agreements, ${ }^{41}$ the NCC could become even more attractive as a forum that addresses international commercial disputes. As a result of the Brexit, there is uncertainty about the enforceability of the judgments of the London Commercial Court within the EU. In the case of a 'hard Brexit' (the 'no-deal scenario'), the UK will not be part of the EU framework of civil judicial cooperation. The Brussels I Regulation (recast) would no longer apply to the UK. This would also be the case with regard to the Lugano Convention, but the UK could apply to rejoin this convention in its own right. The same applies to the Choice of Court Convention. ${ }^{42}$ All this is certainly to the advantage of other commercial courts in member states, like the NCC. In this aspect, arbitration will be a stronger competitor of the NCC than London owing to the worldwide enforcement mechanism of the New York Convention. All in all, and with regard to this aspect, the NCC seems to be competitive enough.

A factor that does not emerge in the survey as an important element of choice, but that should not be underestimated, is the 'costs of the proceedings'. As with all goods and services, these will, one way or another, play a role in the business decision made in the international contract. Although the court fees of the NCC do not seem to be very competitive compared with those of London or Singapore, it would be a mistake to focus on this aspect alone when considering the costs of litigation before a business court. Court fees are only a very small part of the total costs of litigation in international commercial cases. These costs are largely determined by the costs of the legal services that are connected to litigation. In this respect, the NCC is more competitive, as these costs are much lower in the Netherlands than in London and

39. Regulation (EU) $1215 / 2012$ of the European Parliament and of the Council of 12 December 2012 on jurisdiction and the recognition and enforcement of judgments in civil and commercial matters PB L 351/1 van 20 December 2012.

40. Convention on jurisdiction and the recognition and enforcement of judgments in civil and commercial matters, OJ L 339, 21 December 2007, at 3-41.

41. Hague Convention of 30 June 2005 on Choice of Court Agreements. See for the status of ratifications, available at: https://www.hcch.net/ en/instruments/conventions/status-table/?cid=98 (last visited December 2018).

42. The UK government published a guidance note on 13 September 2018 on the consequences of a hard Brexit for the handling of civil legal cases, available at: https://www.gov.uk/government/publications/ handling-civil-legal-cases-that-involve-eu-countries-if-theres-no-brexitdeal/handling-civil-legal-cases-that-involve-eu-countries-if-theres-nobrexit-deal (last visited in December 2018). 
Singapore. ${ }^{43}$ In the NCC plan of the Dutch Council for the Judiciary that was mentioned earlier, it is estimated that a procedure in London is five times as expensive as in Amsterdam. ${ }^{44}$ In addition to this, the efficiency of the proceedings should be taken into consideration. Costs will be lower, as the proceedings are more efficient. The same goes for the costs of disclosure. More restrictive disclosure rules will lead to lower costs; hence the pilot in the London Commercial Court, as mentioned earlier. Considering what has been described earlier about the NCC proceedings, it is safe to say that in these aspects the NCC seems to have a favourable position. Finally, it is important to note that in the Dutch system the winner of the case will not get full restitution of the legal fees, as in the English system, and this can work as an incentive against excessive litigation costs. It can therefore be expected that the NCC will be competitive in regard to costs.

Finally, the survey focuses on the choice between national (business) courts, while it is obvious that not only other business courts form the competitors of the NCC, but even more so the international commercial arbitration practice. Without going into a detailed comparison between the two, one element catches the eye. It is often stated that one of the reasons why businesses choose (contractual) arbitration is confidentiality. ${ }^{45}$ Businesses attach great importance to this, for reasons such as a concern for their reputation or the potential impact on share prices. Although judges have some possibilities to order that a hearing take place behind closed doors, these are very restricted, and the NCC will not be able to accommodate this confidentiality in the same way as arbitration. I do not think this is a problem for the NCC. The London Commercial Court also does not offer confidentiality. On the contrary, the cases often attract a great deal of interest from investors, and the courtroom is full of financial journalists or bloggers who report 'real-time', with a possible real-time effect on share prices. On the basis of the success of the London Commercial Court, it is fair to state that this practice apparently does not seem to scare parties.

\section{Possible Influence on Dutch Civil Litigation}

The final question addressed here is whether the establishment of the NCC will have an effect on civil procedural law and practice in the Netherlands. It is likely that this will further strengthen the growing dominance

43. See the comparison of the costs of dispute resolution made by Brouwer and Butijn, above n. 2, at 155-85.

44. NCC-Plan, at. 17

45. See, e.g., the 2018 International Arbitration Survey: The Evolution of International Arbitration conducted by the School of International Arbitration at Queen Mary University of London. The survey shows that $87 \%$ of respondents believe that confidentiality in international commercial arbitration is of importance. Most respondents think that confidentiality should be an opt-out, rather than an opt-in, feature. of the Anglo-American legal system. Dutch civil procedure will move further in the direction of common law, more specifically in that of English law. This may sound paradoxical at first hearing; after all, the hegemony of the London Commercial Court and English law in the field of international trade disputes seems to diminish by the establishment of business courts, like the NCC, in other countries, so why should this strengthen the dominance of that same English law? Because these new business courts will have the tendency - at least for the NCC this is the case, as shown earlier - to adopt the successful elements from the London procedure and integrate them into the rules of proceedings or even procedural law. Moreover, English is adopted as the language of communication in these proceedings.

The question is whether this effect will be limited to the business courts. This is not a realistic expectation; after all, why should elements that prove to work well in NCC procedures be withheld from parties in other cases? In addition, the establishment of an NCC seems to fit well with developments in other areas of civil justice. Especially since the turn of the millennium, modernisation of Dutch procedural law has already been heavily influenced by the civil procedural law of England and Wales, prompted mainly by the introduction of the so-called "Woolf reform" of 1999. This reform strongly influenced the thinking about the modernisation of civil litigation and, ultimately, also later legislation in this field. ${ }^{46}$ In a recent advice from an expert group on the modernisation of the civil law of evidence, this influence is again recognisable. This time this influence is not derived entirely from English law but equally (or even stronger) from the international arbitration law and the Principles of Transnational Civil Procedure drawn up by Unidroit and the American Law Institute, both of which have a strong common law signature. This concerns, for example, the possibility of witness examination by someone other than the judge and the use and status of written witness statements in Dutch procedural law. This is in line with one of the central themes of the advice, namely to shift the centre of gravity of the procedure and the taking of evidence to the early stages of the proceedings ('the pretrial phase'). With regard to the issue of disclosure outlined earlier, it is noteworthy that the expert group recommends that new rules on this issue be broader than the current Article 843 a CCP but clearly more restrictive than current English law. As stated earlier, such rules could become an (extra) selling point when applied by the NCC.

The recommendations have already been put into draft legislation and subjected to Internet consultation in the spring of $2018,{ }^{47}$ and a bill is currently being prepared. When this bill is adopted by parliament, Dutch civil litigation will again move more in the direction of common law.

46. This influence is clearly recognisable in the reports and recommendations of the Committee on Revision of Dutch Civil Procedural Law of 2003 and 2006

47. See www.internetconsultatie.nl/bewijsrecht (last visited in December 2018). 


\section{Conclusion}

This article has argued that with the establishment of the NCC, Dutch civil litigation will increasingly start to show the characteristics of common law (especially 'English'). Although the special rules in the NCCR and possible agreements as to proceedings in the first instance will be limited to NCC cases, a proven success will lead to a call to implement these adjustments in other cases as well. The article has also argued that these changes fit in with the broader picture of the modernisation of Dutch civil procedural law in (roughly) the past two decades, particularly in respect of case management, term monitoring and direction of the case by the judge. This trend can also be recognised in the recent recommendations of the expert group on civil evidence law and the draft legislation based on these recommendations that is on its way to parliament.

These developments can, in turn, be placed within the broader trend of a growing dominance of the English language in combination with globalisation. This dominance has been visible for a much longer time in areas such as trade, technology, science and culture, and civil law does not stay unaffected by it. The use of English terminology and the concepts of common law has become standard, especially in the field of international trade law and international commercial contracts. The current dominance of English law and the London Commercial Court can therefore be considered to be the result of this broader trend. It is hard to predict whether the upcoming Brexit and the rise of other international business courts will be able to 'bend the trend'. As far as the NCC is concerned, the primary challenge will be to break through the unjustified prejudice against Dutch contract law and to make a flawless start. As the saying goes, 'you never get a second chance to make a first impression'. 